\title{
CHILDREN CARE MAINSTREAMING SEBAGAI UPAYA PENCEGAHAN KEKERASAN TERHADAP ANAK DI KOTA SEMARANG
}

\author{
Rudi Salam, Didi Pramono, Noviani Achmad Putri \\ Jurusan Pendidikan IImu Pengetahuan Sosial, UNNES \\ E-mail: rudisalam@mail.unnes.ac.id
}

\begin{abstract}
Abstrak
Artikel bertujuan mengkaji tingkat kekerasan terhadap anak, menganalisis kondisi kelayakan lingkungan hidup bagi anak-anak; dan mengembangkan model Children Care Mainstreaming. Hasil penelitian tingkat kekerasan di Kota Semarang masih dikategorikan tinggi, tertinggi di Jawa Tengah. Angka kekerasan berjumlah 244 kasus, yang terdiri atas kasus kekerasan terhadap perempuan (169 kasus), kekerasan terhadap anak (67 kasus), dan anak berkonflik dengan hukum (8 kasus). Kondisi kelayakan lingkungan hidup masih perlu mendapatkan perhatian khusus, karena ada beberapa indikator Kota Layak Anak (KLA) yang belum terpenuhi. Misal (1) masih banyak anak yang belum dibebaskan dari bentuk pekerjaan terburuk anak; (2) belum banyak lembaga kemasyarakatan yang terlibat dalam pemenuhan hak anak; (3) belum ada sekolah yang memiliki program, sarana, dan prasarana perjalanan anak ke dan dari sekolah; (4) belum ada mekanisme penanggulangan bencana yang memperhatikan kepentingan anak. Model Children Care Mainstreaming yang dikembangkan dalam penelitian ini dinamakan dengan One Month Report. Program ini merupakan laporan yang disusun oleh sekolah (guru kelas) terkait dengan tujuh aspek afektif anak yang akan diberikan kepada orang tua siswa yakni religiusitas, etika, komunikasi, pertemanan, minat dan bakat, gaya belajar, dan capaian pembelajaran.
\end{abstract}

Kata Kunci : Children Care Mainstreaming, Child Abuse

Abstract

The study are assess the level of violence against children, analyze the feasibility conditions of living environment for children, and develop a model that supports the Children Care Mainstreaming child protection efforts. The results are level of violence in the city of Semarang are still categorized as high, even the highest in Central Java. Figures violence amounted to 244 cases, consisting of cases of violence against women (169 cases), child abuse (67 cases), and children in conflict with the law (8 cases). Environmental feasibility conditions still deserve special attention, because there are some indicators Kota Layak Anak (KLA) which have not been met. Example (1) there are still many children who have not been liberated from the worst forms of child work; (2) has not been a lot of community organizations involved in the fulfillment of children's rights; (3) there are no schools that have programs, facilities, and infrastructure for children traveling to and from school; (4) there is no disaster management mechanism that takes into account the interests of the child. Children Care Mainstreaming Model developed in this study is called the "One Month Report". The program is a report compiled by the school (classroom teachers) associated with affective aspects of seven children who will be given to the parents which are religiosity, ethics, communication, friendships, interests and talents, learning styles, and learning outcomes. Keywords: Children Care Mainstreaming, Child Abuse 


\section{Pendahuluan}

Anak merupakan amanah dari Allah SWT yang harus dijaga oleh orang tua dan manusia dewasa yang ada di sekitar kehidupannya. Anakanak belum memiliki kemampuan sempurna seperti yang dimiliki oleh manusia dewasa. Anak-anak sejatinya masih sangat membutuhkan perlindungan dan bimbingan dari orang tua. Anak harus dilindungi dari alam dan lingkungan sekitar, dari manusia dan makhluk hidup lain yang ada di sekitarnya, dan dilindungi dari ancaman bahaya yang mungkin terjadi. Anak-anak juga harus dibimbing agar bisa melakukan cara-cara hidup sebagaimana masyarakat kebanyakan mempraktikkan-nya. Anak dibimbing untuk berperilaku, bertutur kata, dan bersikap baik kepada semua orang yang ada di sekitarnya.

Fakta tidak selalu se-ideal itu, di masyarakat masih sering dijumpai tindak kekerasan terhadap anak. Bahkan tindak kekerasan tersebut dilakukan oleh orang-orang terdekat, seperti orang tua, paman, tetangga, atau orang-orang terdekat yang ada di sekitar kehidupan anak. Data Komisi Perlindungan Anak Indonesia (KPAI) menyatakan kekerasan pada anak selalu meningkat setiap tahun. Hasil pemantauan KPAI dari 2011 sampai 2014, terjadi peningkatan yang sifnifikan.

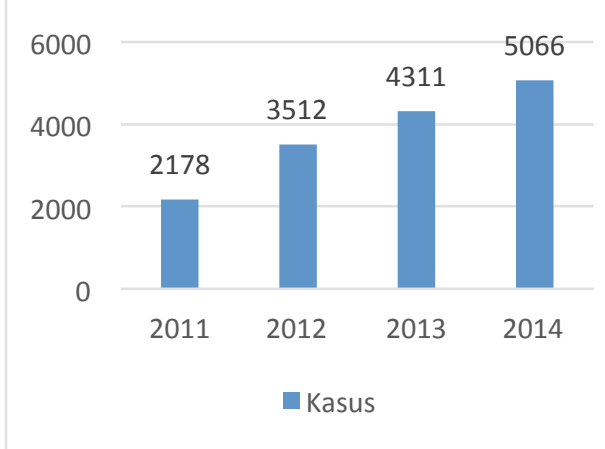
Gambar 1. Grafik Peningkatan Kasus Kekerasan terhadap Anak Sumber: www.kpai.go.id

Gambar di atas menggambarkan dengan jelas jumlah kekerasan terhadap anak yang terus mengalami peningkatan. Tahun 2011 terjadi 2178 kasus kekerasan, 2012 ada 3512 kasus, 2013 ada 4311 kasus, 2014 ada 5066 kasus. Kasuskasus tersebut terjadi dalam berbagai kondisi. Setidaknya ada lima kondisi di mana anak mendapatkan perlakuan tindak kekerasan, diantaranya, anak berhadapan dengan hukum, kasus di dunia pendidikan kasus di bidang kesehatan dan napza, serta kasus pornografi dan cybercrime. 


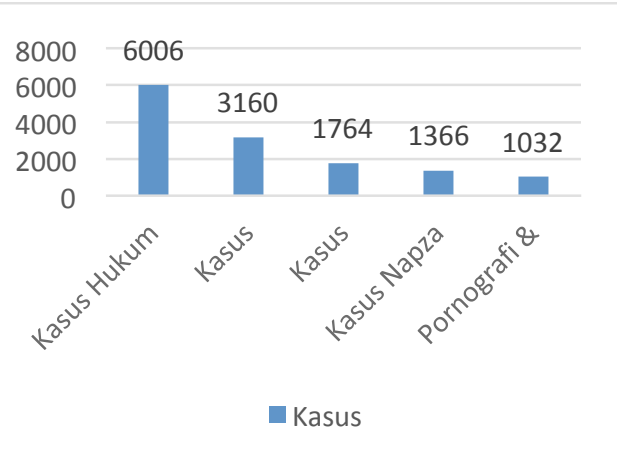

Gambar 2 Bidang-Bidang Kasus Kekerasan terhadap Anak Sumber: www.kpai.go.id

Gambar menunjukkan bidangbidang di mana anak menjadi korban kekerasan. Kasus kekerasan terhadap anak di bidang hukum memiliki kasus terbanyak, dengan total 6.006 kasus, bidang pengasuhan sebanyak 3.160 kasus, di bidang pendidikan sebanyak 1.764 kasus, kesehatan dan penyalahgunaan napza sebanyak 1.366 kasus, serta pornografi dan cybercrime sebanyak 1.032 kasus. Selain bidang-bidang kasus tersebut, ada juga kasus perdagangan anak (human trafficking) dan eksploitasi terhadap anak. Berikut data yang berhasil dihimpun dari www.kpai.go.id.

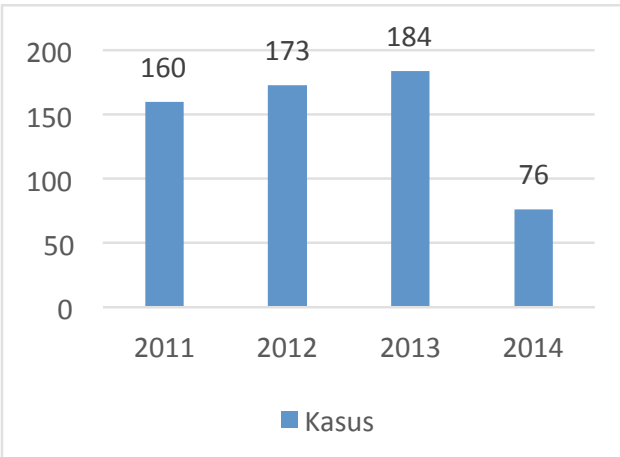

Gambar 3 Data Kasus Perdagangan Anak dan Eksploitasi terhadap Anak Sumber: www.kpai.go.id

Gambar 3 menunjukkan betapa kasus kekerasan terhadap anak semakin beragam, yakni perdagangan anak (human trafficking) dan eksploitasi terhadap anak. Bahkan kasus-kasus tersebut terus meningkat secara kuantitas. Kasus perdagangan anak (human trafficking) dan eksploitasi terhadap anak tahun 2011 terjadi sebanyak 160 kasus, tahun 2012 terjadi sebanyak 173 kasus, tahun 2013 terjadi sebanyak 184 kasus, dan tahun 2014 (Januari hingga April) terjadi sebanyak 76 kasus. Kasuskasus tersebut bahkan kencenderungannya justru terjadi di lingkungan terdekat anak, seperti lingkungan keluarga, sekolah, dan masyarakat sekitar.

Tentu kita masih ingat kasus yang menimpa almarhum Anggeline, bocah berusia 8 tahun yang meninggal karena tindak kekerasan yang dilakukan oleh ibu angkatnya, 
Margriet. Kasus lain seperti kasus pembunuhan anak dalam kardus, kasus pencabulan di sekolah internasional JIS, dan terakhir penganiayaan anak usia 12 tahun oleh oknum TNI di kompleks perumahan TNI Cilandak.

Berdasarkan masalah-masalah yang terpapar dalam data dan fakta di atas, dapat dikatakan bahwa kasus kekerasan terhadap anak sungguh sangat mengkhawatirkan. KPAI bahkan menyebut "Indonesia darurat kejahatan kekerasan terhadap anak". Menanggapi hal tersebut, perlu dikembangkan sebuah model upaya perlindungan anak agar penanganan kasus ini bisa benar-benar tuntas dan bahkah bisa dicegah sedini mungkin sebelum kasus tersebut terjadi. Pengembangan model ini ditujukan untuk semakin memperkuat langkah KPAI dan implementasi UU No. 35 Tahun 2014 tentang perlindungan anak.

Children Care Mainstreaming merupakan langkah inovatif untuk mencoba ikut menangani masalah kekerasan terhadap anak. Model perlindungan anak ini masih perlu dicarikan formulasi yang paling tepat. Salah satu langkah strategisnya adalah melalui penelitian pengembangan ini, yang berjudul "Children Care Mainstreaming sebagai Upaya Pencegahan Kekerasan terhadap Anak di Kota Semarang".

Berdasarkan latar belakang di atas penelitian ini mengkaji kondisi tingkat kekerasan terhadap anak di Kota Semarang, kondisi kelayakan lingkungan hidup bagi anak-anak di Kota Semarang dan pengembangan model Children Care Mainstreaming yang mendukung upaya perlindungan anak di Kota Semarang.

\section{Metode}

Pendekatan penelitian yang digunakan dalam penelitian ini adalah penelitian dan pengembangan (Research and Development), dengan dilakukan penyederhanaan langkah, dari sepuluh langkah (Borg dan Gall, 2003: 571), menjadi tiga tahap, yaitu studi pendahuluan, pengembangan, dan validasi. Penelitian ini dilakukan di Kota Semarang, secara spesifik di wilayah-wilayah dengan potensi tindak kekerasan terhadap anak yang tinggi. Misal di daerah Kota Lama yang memiliki karakteristik masyarakat marginal. Subjek penelitian ini secara spesifik dikhususkan kepada kelompok ibuibu PKK Kelurahan Kauman Kec. Semarang Tengah Kota Semarang. 
Teknik analisis data pada penelitian ini seluruhnya dilakukan secara kualitatif. Data-data yang diperoleh baik pada tahap pendahuluan, pengembangan, hingga data-data pada tahap validasi dianalisis menggunakan teknik kualitatif. Teknik kualitatif yang dimaksud dalam hal ini adalah teknik triangulasi data, dengan metode membandingkan sumber data.

Pada tahap pendahuluan, datadata yang sifatnya sekunder dibandingkan dengan data-data dari sumber sekunder lain, dan juga data dari hasil observasi awal. Pada tahap pengembangan, data-data yang bersumber dari hasil penelitian dianalisis dengan data-data lain yang bersumber dari verifikasi terbatas pada kelompok sosial tertentu dan data hasil dari uji ahli.

Data-data pada tahap validasi juga dianalisis menggunakan teknik triangulasi, dengan jalan membandingkan data-data hasil evaluasi dan penyempurnaan model dengan data hasil dari uji coba pada kelompok model/imbas. Interaksi antara dua data ini kemudian dianalisis secara kualitatif, yang kemudian menjadi data final tentang pengembangan model perlindungan anak Children Care Mainstreaming.

\section{Hasil dan Pembahasan}

\section{Kondisi Tingkat Kekerasan terhadap Anak di Kota Lama Semarang}

Kota Semarang merupakan wilayah yang memiliki angka kekerasan terhadap anak yang paling tinggi di daerah Jawa Tengah. Berdasarkan laporan tahunan PPT Seruni, diketahui bahwa jumlah kasus kekerasan di Kota Semarang tercatat sebanyak 244 kasus, yang terdiri dari kasus kekerasan terhadap perempuan sebanyak 169 kasus, kasus kekerasan terhadap anak sebanyak 67 kasus, dan anak berkonflik dengan hukum sebanyak 8 kasus. Kasus kekerasan tersebut tersebar di seluruh kecamatan di wilayah kota Semarang. Jumlah kasus tertinggi terjadi di wilayah Kecamatan Semarang Timur, dimana kekerasan yang dilaporkan sebanyak 34 kasus kekerasan (Nugrahani, 2015 : 5). Catatan terakhir yang dibubukan oleh PPT Seruni menunjukkan angka 244 kasus kekerasan terhadap anak. Kasuskasus tersebut pun bervariasi, mulai dari kekerasan seksual, fisik, psikis, dan penelantaran. Bentuk-bentuk kekerasan fisik seperti terpapar pada tabel 5.2 di atas terjadi karena banyak faktor, diantaranya kenakalan remaja, persoalan keluarga, kondisi 
ekonomi,

immaturitas/ketidakmatangan orang tua, kurangnya pengetahuan menjadi orang tua, harapan yang tidak realistis terhadap kemampuan dan perilaku anak, isolasi sosial, gangguan jiwa pada orang tua, dan pengalaman negatif orang tua di masa lampau (Nugrahani, 2015: 7-8).

2. Kondisi Kelayakan Lingkungan

Hidup bagi Anak-Anak di Kota

\section{Lama Semarang}

Kelayakan lingkungan hidup bagi anak-anak di Kota Lama Semarang diukur berdasarkan indikator Kota Layak Anak seperti tertuang dalam Peraturan Menteri Pemberdayaan Perempuan dan Perlindungan Anak Nomor 12 Tahun 2011 tentang Indikator Kabupaten/Kota Layak Anak. Bab III pada Permen tersebut menjelaskan:

"Suatu kabupaten/kota dapat disebut layak anak, apabila memenuhi 31 (tiga puluh satu) Indikator KLA. Indikator KLA dikembang-kan mengacu pada Konvensi Hak Anak (KHA) dan peraturan perundang-undangan terkait anak".

Kota Semarang masih terdapat beberapa aspek kehidupan di Kota Semarang yang belum memenuhi kriteria Kota Layak Anak (KLA). Data menyebutkan pada Indikator 1 dari Peraturan Menteri Pemberdayaan Perempuan dan Perlindungan Anak
Nomor 12 Tahun 2011 tentang Indikator Kabupaten/Kota Layak Anak, terdapat beberapa indikator yang belum mencapai kata layak. Misal (1) belum optimalnya ketersediaan sumber daya manusia (SDM) terlatih KHA dan mampu menerapkan hak anak ke dalam kebijakan program dan kegiatan; (2) belum banyak lembaga kemasyarakatan yang terlibat dalam pemenuhan hak anak; dan (3) keterlibatan dunia usaha dalam pemenuhan hak anak. Tiga indikator ini tentu menyisakan pekerjaan rumah bagi pemangku kebijakan untuk mencapai tujuan Semarang sebagai Kota Layak Anak. Data pada Indikator 2 pun menunjukkan hasil yang belum optimal. Mulai dari (1) persentase anak yang teregistrasi dan mendapatkan Kutipan Akta Kelahiran; (2) ketersediaan lembaga konsultasi bagi orang tua/keluarga tentang pengasuhan dan perawatan anak; dan (3) ketersediaan lembaga kesejahteraan sosial anak. Indikatorindikator ini tersedia, namun dalam pengelolaannya belum optimal. Hal ini berimplikasi pada perlindungan anak yang juga belum optimal.

Data pada Indikator 3 relatif menunjukkan data positif. Hal ini berarti kesehatan dasar dan kesejahteraan masyarakat dan anak- 
anak terjamin baik. Indikator 4 terdapat satu aspek yang belum optimal di Kota Semarang, yakni jumlah sekolah yang memiliki program, sarana, dan prasarana perjalanan anak ke dan dari sekolah. Indikator ini sebenarnya penting untuk dipenuhi, mengingat beberapa siswa (anak) memiliki jarak tempuh dan karakteristik jalan yang berbeda satu sama lain. Program, sarana, dan prasarana perjalanan anak ke dan dari sekolah ini berupa bus sekolah yang di sediakan oleh pihak sekolah, namun memang masih sedikit yang masih memiliki fasilitas tersebut. sebagian besar yang memiliki fasilitas ini merupakan sekolah swasta atau negeri yang dirasa sudah cukup maju. Di satu sisi, angka kejahatan terhadap anak yang terjadi di-jalanan juga kerang kali terjadi dan menimpa anak-anak.

Indikator 5 terkait dengan bentuk perlindungan khusus terhadap anak. Pada indikator ini pun ada 2 aspek yang belum optimal dikerjakan oleh pemerintah, yakni (1) adanya mekanisme penanggulangan bencana yang memperhatikan kepentingan anak; dan persentase anak yang dibebaskan dari bentuk-bentuk pekerjaan terburuk anak. Poin (1) dikatakan belum optimal karena sejauh ini masih sangat jarang atau bahkan belum pernah sama sekali anak-anak diikutkan dalam pendidikan tanggap bencana. Orang tua pun, sangat jarang yang mengikuti program pendidikan tanggap bencana. Hal ini disebabkan oleh tidak adanya pendidikan tanggap bencana yang diprogramkan pemerintah. Poin (2) dikatakan belum optimal karena masih sering dijumpai anak-anak yang hidup di jalanan, baik itu menjual koran, mengamen, berjualan asongan, mengemis, dan aktivitas anak jalanan lainnya. Berdasarkan hasil penelitian tentang tingkat kekerasan terhadap anak dan 5 indikator Kota Layak Anak seperti djabarkan di atas, maka perlu dikembangkan sebuah model perlindungan anak yang disusun seccara sistematis dan komprehensif. Rancangan model perlindungan anak dijelaskan secara rinci pada sub bab 5.3 tentang Rancangan Model Perlindungan Anak di Masyarakat Kota Lama Semarang.

\section{Rancangan Model Perlindungan} Anak di Masyarakat Kota Lama

\section{Semarang}

Revisi dan rekomendasi ini kemudian menjadi bahan kajian tim peneliti untuk mengembangkan model perlindungan anak yang spesifik. Children Care 
Mainstreaming yang dihasilkan dari penelitian ini dinamakan dengan One Month Report.

One Month Report merupakan program perlindungan anak yang melibatkan partisipasi dua agen sosialisasi, yakni orang tua dan sekolah. Singkat kata, program ini mencoba mengkorelasikan antara orang tua dengan sekolah. Orang tua merupakan pihak yang memiliki anak, agen yang paling dekat dengan anak, dan agen yang paling berhak atas pengasuhan anak. Idealnya, peran orang tua sangat vital bagi tumbuh kembang anak. Di satu sisi, sekolah merupakan pihak ketiga yang dalam beberapa hal dipasrahi untuk mengemban tanggung jawab dalam mendidik anak. Anak-anak akan berada di sekolah dari jam 06.00 sampai 12.00 atau bahkan hingga pukul 15.00 (SD, SMP, dan SMA), dengan demikian anak-anak pada jam tersebut mendapatkan sosialisasi nilai-nilai dari sekolah. Karakteistik sekolah inilah yang menjadikan sekolah sebagai agen sosialisasi yang strategis dalam upaya mengatasi kekerasan terhadap anak. Sekolah harus terkoneksi dengan orang tua. Sekolah justru jangan menjadi lembaga sosial yang terlepas sama sekali dengan orang tua dan masyarakat. Sekolah mestinya menjadi mitra bagi orang tua dan masyarakat dalam membangun karakter anak. Sekolah harus bisa memberikan informasi yang akurat kepada orang tua mengenai perkembangan anak, tidak hanya perkembangan akademik tetapi juga perkembangan emosional, karakter, keterampi-lan, minat, dna bakat anak. Demikian juga sebaliknya, orang tua juga bisa memberikan informasi kepada sekolah terkait dengan halhal yang bersifat pribadi dari anak.

Intinya, One Month Report merupakan laporan yang disusun oleh sekolah (guru kelas) terkait dengan 7 aspek afektif anak yang akan diberikan kepada orang tua siswa. Tujuh aspek afektif yang menjadi bahan laporan diantaranya:

a. Religiusitas

Aspek religiusitas meliputi aktivitas keagamaan anak, yakni mengenai bagaimana anak menjalakan segala perintah-Nya dan menjauhi segala larangan-Nya. Apakah anak rajin beribadah selama berada di sekolah, apakah anak menjalankan ajaran-ajaran agama dengan baik di sekolah. Sekolah (guru kelas) harus bisa memotret aktivitas-aktivitas siswa tersebut dengan baik, dan melaporkannya ke orang tua siswa. 
b. Etika

Aspek etika meliputi segala tingkah laku anak selama di sekolah, yakni mengenai bagaimana anak berbuat baik kepada guru, sesama teman, dan orang-orang lainnya yang ada di sekitar lingkungan sekolah. Sekolah (guru kelas) tentu harus mengamati tingkah laku anak, sejauh pengamatan yang bisa dijangkaunya.

c. Komunikasi

Aspek komunikasi meliputi keterampilan anak dalam menyampaikan pesan kepada orang lain dengan tuturan yang santun, dengan tetap menjunjung tinggi adat istiadat yang berlaku di masyarakat. Keterampilan berkomunikasi ini mencakup komunikasi dengan guru, teman sepermainan, dan orangorang lainnya yang ada di sekitar lingkungan sekolah.

d. Pertemanan

Aspek pertemanan meliputi rekam jejak pertemanan anak dari dulu hingga kini selama berada di lingkungan sekolah. Aspek ini penting untuk memotret siapa saja yang menjadi teman anak selama bergaul di lingkungan sekolah. Orang tua penting untuk mengetahui hal ini, mengingat karakter anak juga sangat dipengaruhi oleh pertemanan. e. Minat dan Bakat

Aspek minat dan bakat meliputi hal-hal yang menjadi kegemaran anak selama melakukan aktivitas di lingkungan sekolah. Minat dan bakat ini penting untu dipotret dengan baik oleh sekolah (guru kelas), dan untuk kemudian dilaporkan kepada orang tua, karena dengan demikian maka sekolah (guru kelas) dan orang tua bisa mengarahkan masa depan anak sesuai dengan passion-nya.

f. Gaya Belajar

Aspek gaya belajar meliputi cara-cara, strategi, dan pola belajar anak selama menempuh pendidikan di sekolah. Aspek ini penting dilaporkan kepada orang tua agar orang tua bisa mengetahui potensi akademik anak dan dapat mengarahkan anak sesuai dengan gaya belajarnya.

g. Capaian Pembelajaran

Aspek capaian pembelajaran meliputi hasil-hasil yang didapatkan anak selama menempuh pendidikan sekolah. Capaian pembelajaran ini harus dimaknai secara luas, karena tidak hanya capaian dalam ranah kognitif saja melainkan juga ranah afektif dan psikomotorik. Hal-hal semacam ini juga perlu dilaporkan kepada orang tua agar orang tua bisa turut memberikan reward jika anak 
berprestasi atau penguatan jika anak memiliki masalah dalam belajarnya.

Tujuh aspek afektif ini selanjutnya dijabarkan dalam bentuk instrumen penilaian afektif. Pengembangan instrumen ini ditujukan untuk mempermudah sekolah (guru kelas) dalam menyusun laporan. Selain itu juga mempermudah orang tua untuk menerjemahkan laporan yang telah disusun sekolah (guru kelas). Program One Month Report ini rasional untuk diimplementasikan sebagai langkah pencegahan tindak kekerasan terhadap anak. Hal ini didasarkan pada pertimbanganpertimbangan di atas. Selain itu, program One Month Report bersifat melengkapi program-program yang sudah ada sebelumnya, yakni program-program yang sudah dicanangkan oleh pemerintah, seperti Program 18-21 dan GN Aksa.

Program 18-21 merupakan anjuran kepada masyarakat untuk memberikan waktunya yang berkualitas untuk anak, yakni pada pukul 18.00 hingga pukul 21.00 fokus untuk melakukan 3B, yakni Berjamaah bersama, Belajar bersama, dan Berbicara bersama. Orang tua harus menanggalkan sementara semua pekerjaannya, gadget-nya, dan semua urusan- urusan di luar urusan rumah tangga. Hal ini ditujukan agar orang tua fokus untuk memberikan kasih sayangnya kepada keluarga. Jika dianalisis, maka ranah dari program ini adalah keluarga pada umumya. Tentu akan berbeda lagi jika kita menilik program GN-Aksa

Program GN-Aksa merupakan singkatan dari Gerakan Nasional Anti Kekerasan Seksual terhadap Anak. Sesuai dengan Instruksi Presiden Republik Indonesia Nomor 4 tahun 2014 tentang Gerakan Nasional Anti Kekerasan Seksual terhadap Anak, maka presiden menginstruksikan kepada para Menteri, Jaksa Agung, Kepala Kepolisian Negara Republik Indonesia, Kepala Lembaga Pemrintahan Non Kementerian, Gubernur, dan Bupati/Walikota untuk mengambil langkah-langkah yang diperlukan sesuai tugas, fungsi, dan kewenangan masing-masing secara terkoordinasi dan terintegrasi dalam rangka melakukan pencegahan dan pemberantasan kejahatan seksual terhadap anak melalui Gerakan Nasional Anti Kejahatan Seksual Terhadap Anak (GN-AKSA) dengan melibatkan seluruh unsur masyarakat dan dunia usaha.

Program GN-Aksa ini tentu memiliki cakupan yang luas dan menyasar kepada lembaga-lembaga 
negara. Karakteristik ini tentu berbeda dengan program 18-21 dan terlebih dengan program One Month Report. Berdasarkan pemahaman inilah, maka dapat dikatakan bahwa Program One Month Report bersifat melengkapi (komplementer) terhadap program-program yang sudah ada sebelumnya, yakni program yang sudah dicanangkan oleh pemerintah, yaitu program 18-21 dan GN-Aksa. Harapannya dengan semakin banyak program-program pencegahan kekerasan terhadap anak dapat semakin meminimalisir atau bahkan meniadakan sama sekali kejahatan terhadap anak.

\section{Simpulan}

Simpulan penelitian ini adalah data dan fakta menyebutkan bahwa Kota Semarang masih memiliki indeks kekerasan terhadap anak yang relatif tinggi bila dibandingkan dengan daerah-daerah lain di Jawa Tengah. Data awal tentang tingkat kekerasan terhadap anak di Kota Semarang ini menjadi rasional untuk dikembangkannya model perlindungan anak Children Care Mainstreaming. Sumber data sekunder mengenai indikator Kota Layak Anak pun belum bisa disematkan pada Kota Semarang, karena jika dilihat dari data, masih ditemukan beberapa kekurangan pada aspek-aspek tertentu. Kecenderungannya, indikator KLA yang dikategorikan kurang adalah pada aspek fisik (sarana dan prasarana). Kota Semarang belum sepenuhnya mampu membangun sarana dan prasarana untuk menunjang Semarang sebagai Kota Layak Anak, mungkin ini permasalahan APBD. Kondisi inipun pada akhirnya menjadi rasional untuk dikembangkannya model perlindungan anak Children Care Mainstreaming. Dengan konstruksi berpikir bahwa "jika belum mampu untuk membangun sarana dan prasarana fisik, maka bangunlah dulu manusianya" melalui model perlindungan anak Children Care Mainstreaming

Model perlindungan anak Children Care Mainstreaming, untuk sementara ini, yang paling efisien untuk diimplementasikan adalah Children Care Mainstreaming melalui Program One Month Report. Program ini menjadi rasional karena program ini cukup sederhana, karena hanya melibatkan dua agen sosialisasi, sehingga sinergitas diantara keduanya mudah dibangun. Selain itu, menjadi semakin rasional karena program ini melibatkan sekolah (guru kelas) untuk membuat laporan- 
laporan terkait dengan aspek afektif anak, mengingat rata-rata anak menghabiskan waktu kurang lebih 8 jam berada di sekolah. Tak pelak, sekolah (guru kelas) menjadi significant other bagi perkembangan karakter anak. Posisi ini menempati posisi strategis, sehingga memang Children Care Mainstreaming melalui Program One Month Report logis untuk diimplementasikan. Hal ini semakin diperkuat oleh adanya dukungan dari masyarakat yang memang menginginkan adanya koordinasi yang baik antara sekolah dengan orang tua, agar orang tua tahu bagaimana perkembangan anaknya selama di bangku sekolah.

\section{Ucapan Terima Kasih}

Tim Peneliti mengucapkan terima kasih kepada semua pihak yang mendukung penelitian ini serta tim redaksi Jurnal Dimensia yang menerbitkan artikel ini.

\section{Daftar Pustaka}

Borg, W. R. \& Gall, M. D. 2003.

Educational research: an introduction (7th ed.). New York: Longman, Inc.

Margaretha; Nuringtyas, Rahmaniar; dan Rani Rachim. 2013.

Trauma Kekerasan

Masa Kanak dan Kekerasan dalam Relasi Intim. Jurnal Makara Seri Sosial Humaniora. Volume 17(1). Halaman 33-42.

Nindya, P.N., dan Margaretha R.
2012. Hubungan antara Kekerasan Emosional pada Anak terhadap Kecenderungan Kenakalan Remaja. Jurnal Psikologi Klinis dan Kesehatan Mental. Volume 1, No. 02, Juni 2012. Nugrahani, Selma. 2015. Hubungan Parenting Stress dengan Kecenderungan Perilaku Kekerasan terhadap Anak. Skripsi. UNNES:

Semarang Pasalbessy, Jhon D. 2010. Dampak Tindak Kekerasan terhadap Perempuan dan Anak Serta Solusinya. Jurnal Sasi. Volume 16. No. 3. Bulan Juli- September 2010.

Unicef. 2012. Ringkasan Kajian Perlindungan Anak. Unicef Indonesia Widiastuti, Daisy dan Rini Sekartini. 2005. Deteksi Dini, Faktor Resiko, dan Dampak Perlakuan Salah pada Anak. Jurnal Sari Pediatri. Volume 7, No. 2, September 2005. Halaman 105-112. 